\title{
PERAN AKUNTAN DALAM MEWUJUDKAN UNQUALIFIED OPINION LAPORAN KEUANGAN PEMERINTAH DAERAH (LKPD) DI INDONESIA
}

\author{
Oleb \\ Muhsin, SE. MSi., Ak., CA. \\ muhsin_anis@yahoo.co.id \\ Fakultas Ekonomi Universitas Tanjungpura Pontianak \\ Riwayat Artikel: dikirim Oktober 2018, diterima September 2018, diterbitkan September 2018 \\ Abstrak
}

Kemampuan daerah mengelola uang negara, baik uang dari ptisat maupun yang bersumber dari daerah itu, semakin hari malah semakin memburuk.Kenyataan tersebut secara gamblang bisa kita ketahui dari makin sedikitnya laporan keuangan pemerintah daerah (LKPD) yang mendapaskan opini wajar tanpa pengecualian (WTP) dari Badan Pemeriksa Keuangan (BPK). Opini Wajar Tanpa Pengecualian (WTP) tahun 2005, sebanyak 21 LKPD atau (6\%) dari 350 LKPD, tahun 2006 sebanyak 4 LKPD atau (I\%) dari 46I LKPD, tahun 2007 sebanyak 4 LKPD atau (1\%) dari 460 LKPD, dan tahun 2008 sebanyak 12 LKPD atau (3\%) dari 434 LKPD.

Semua itu menunjukkan dengan sangat terang-benderang, betapa rendahnya kompetensi daerah dalam mengelola keuangan negara.Dalam lima tahun terakhir, transfer dana APBN $k e$ daerah meningkat lebih dari dua kali lipat, dari $R p 150,5$ triliun pada 2005 menjadi Rp $309,8 \mathrm{trilim}$ pada RAPBN 2010 Apakah yang akan terjadi bila jumlah uang negara yang harus dikelola terus membengkak, tetapi sebaliknya kemampuan untuk mengelolanya semakin merosot

Kata kunci : $L K P D$, ungtalified opinion 


\section{A. Latar belakang}

Tuntutan perubahan paradigma dalam kehidupan bernegara masih terus menggema.Salah satu tuntutan utama masyarakat pada era reformasi saat ini adalah perbaikan kinerja pemerintah. Perbaikan kinerja birokrasi menjadi perhatian dan isu penting, terutama dengan dikeluarkannya laporan dari The World Competitiveness Yearbook tahun 1999 yang mengemukakan bahwa birokrasi pelayanan publik (public service) di Indonesia berada pada kelompok negara-negara yang memiliki indeks competitiveness paling rendah di antara 100 negara paling kompetitif di dunia Cullen \& Cushman, 2000 dalam (Muhsin ; 2004)

Salah satu amanah agenda reformasi

adalah Undang-Undang No.32 Tahun 2004 Revisi dari Undang-Undang No. 22 Tahun 1999 tentang Pemerintah Daerah dan Undang Undang No. 33 Tahun 2004 revisi dari Undang-Undang No. 25 tahun 1999 tentang Perimbangan Keuangan antara Pemerintah Pusat dan Pemerintah Dacrah, setelah pemerintah Orde Baru berakhir adalah usaha untuk menciptakan sistem pemerintahan yang berbasis otonomi daerah, "Perwujudan otonomi daerah dalam rangka pembangunan daerah dan pemerataan pertumbuhan dalam wadah Negara Kesatuan Republik Indonesia", Untuk mewujudkan misi tersebut maka pemerintah mengeluarkankedua UndangUndang tersebut diatas. Lahirnya kedua Undang-Undang tersebut yang ditandai dengan dibukanya keran wewenang dan tanggungjawab yang semakin besar kepada daerah untuk mengatur daerah itu sendiri, hal ini dikarenakan daerah yang bersangkutan lebih mengetahui kondisi daerah mereka, jadi wajarlah jika mereka juga mempunyai andil besar untuk menata daerahnya.

Pemberian otonomi daerah ini harus disambut baik oleh pemerintah daerah karena selama ini kita sudah terbiasa dengan top down, dengan segala perintah dan wewenang dari pusat (sentralisasi) yang harus dituruti, tanpa boleh bersuara apakah itu sesuai dengan daerah kita atau tidak tetapi diera reformasi sekarang (desentralisasi) bahkan sebaliknya kita diberi kesempatan yang seluas-luasnya untuk berkreasi dan berinovasi tentang apa yang paling diperlukan oleh daerah, dan hal yang paling menarik dan senang didengar oleh masyarakat adalah uang, dimana hal ini akan selalu menjadi sorotan, baik secara individual maupun secara institusional pasti selalu berkaitan erat dengan uang, oleh karena itu sudah selayaknya kita memberikan perhatian sepenunhya kepada makhluk yang satu ini, keuangan yang berkaitan dengan otonomi daerah adalah dimana daerah harus dituntut mampu mengelola keuangan sendiri baik itu pos pendapatan atau penerimaan maupun pos belanja atau pengeluaran, dari sini muncul tanda tanya besar mengapa keuangan daerah ini menjadi primadona dan mendapat sorotan tajam dari berbagai pihak, ada 2 (dua) alasan utama yaitu (1). Uang (money) yang dimiliki dan dikelola oleh pemerintah adalah jumlahnya sangat besar bila dibanding dengan uang yang dimilki dan dikelola oleh rekanrekan kita di sektor privat / perusahaan. (2). Uang yang ada ditangan pemerintah adalah amanah dari rakyat yang harus dipertanggungjawabkan kepada owner'snya yaitu masyarakat Indonesia.

Peran akuntan akhir-akhir ini merupakan profesi yang mendapat sorotan tajam dari masyarakat terkait dengan munculnya berbagai kasus tindak pidana baik yang terjadi pada perusahaan-perusahaan publik dan perusahaan milik negara/daerah serta instansi pemerintahan yang mengakibatkan kerugian pada masyarakat.Akuntan yang dalam menjalankan tugasnya sebagai auditor eksternal memiliki peranan yang sangat penting namun juga rentan terhadap masalah litigasi yang dapat timbul akibat jasa-jasa professional yang diberikannya kepada pemberi kerja (klien).Tidak sedikit statemen dari public menyatakan bahwa biang dari krisis ekonomi adalah akibat peran akuntan yang tidak akuntabel dan profesional,Terlepas dari pro dan kontra tersebut bagaimanapun akuntan saat ini merupakan satu-satunya profesi yang mempunyai kewenangan dan keahlian professional dalam mengaudit laporan keuangan pemerintah daerah baik akuntan yang bekerja di BPK maupun akuntan yang bekerja di KAP, bahkan akuntan yang bekerja di entitas-entitas pemerintah daerah. 
Menurut BPK RI, ditengah hiruk pikuk soal terorisme dan sengketa pilpres, KPK, century ada fakta serius yang luput dari perhatian kita. Serius karena fakta itu menyangkut hajat hidup rakyat di berbagai daerah.Lebih serius lagi karena perkara yang menyangkut hajat hidup rakyat itu tidak kunjung ditangani secara benar dan profesional.Fakta itu ialah pengelolaan keuangan di daerah.

Hari berganti hari, tapi kemampuan daerah mengelola uang negara, baik uang dari pusat maupun yang bersumber dari daerah itu, semakin hari malah semakin memburuk.Kenyataan tersebut secara gamblang bisa kita ketahui dari makin sedikitnya laporan keuangan pemerintah daerah (LKPD) yang mendapatkan opini wajar tanpa pengecualian (WTP) dari Badan Pemeriksa Keuangan (BPK). Opini Wajar Tanpa Pengecualian (WTP) tahun 2005, sebanyak 21 LKPD atau $(6 \%)$ dari 350 LKPD, tahun 2006 sebanyak 4 LKPD atau $(1 \%)$ dari 461 LKPD, tahun 2007 sebanyak 4 LKPD atau ( $1 \%$ ) dari 460 LKPD, dan tahun 2008 sebanyak 12 LKPD atau ( $3 \%$ ) dari 434 LKPD.

Semua itu menunjukkan dengan sangat terang-benderang, betapa rendahnya kompetensi daerah dalam mengelola keuangan negara.Dalam lima tahun terakhir, transfer dana APBN ke daerah meningkat lebih dari dua kali lipat, dari RpI50,5 triliun pada 2005 menjadi Rp309,8 triliun pada RAPBN 2010 Apakah yang akan terjadi bila jumlah uang negara yang harus dikelola terus membengkak, tetapi sebaliknya kemampuan untuk mengelolanya semakin merosot, Menurut Menteri Keuangan Sri Mulyani, Kompas 16 Juli 2008. Susah Cari Akuntan Berkualitas, Hasil Audit BPK terhadap kualitas laporan keuangan pemerintah pusat, kementerian/lembaga serta pemerintah daerah sebagian besar belum memuaskan. Dari uraian diatas maka penulis merumuskan judul dalam makalah ini yaitu "Peran Akuntan Dalam Mewujudkan Unqualified Opinion Laporan Keuangan Pemerintah Daerah (LKPD) di Indonesia"

\section{B. Permasalahan}

Berdasarkan uraian pada latar belakang, maka rumusan masalah pada penulisan ini adalah: "Bagaimana Peran Akuntan dalam mewujudkan Unqualified Opinion Laporan Keuangan Pemerintah Daerah (LKPD) di Indonesia"

\section{Tujuan Penulisan}

Untuk mengetahui sejauh mana peran akuntan dalam mewujudkan Unqualified Opinion Laporan Keuangan Pemerintah Daerah (LKPD) di Indonesia.

D. Manfaat Penulisan

Makalah ini diharapkan akan memberikan manfaatkepada :

1. Bagi Pemerintah Daerah (PEMDA)

Agar menjadi masukan bagi Pemerintah Daerah (PEMDA)dalam menjalankan aktivitas publiknya sesuai dengan aturan (UndangUndang, Peraturan Pemerintah, Keputusan Menteri dan aturan relevan lainnya) dan mengutamakan untuk kepentingan public terutama dalam pengelolaan dan pertanggungiwaban laporan keuangan daerah.

2. Bagi Akuntan

Agar para akuntan mengetahui bahwa di pemerintah daerah peran mereka sangat besar dan perlu meningkatkan professional dalam bekerja serta menjunjung tinggi kode etik akuntandalam menerapkan keahlian dan pengetahuannya. .

3. Bagi Stakeholder

Agar seluruh stakeholder dapat mengetahui dan mendapat informasi tentang pentingnya Peran Akuntan terhadap Laporan Keuangan Pemerintah Daerah (LKPD) supaya fungsi control dan kritis dapat dijalankan terutama yang menyangkut kepentingan public.

\section{E. Metode analisis (literatur)}

Untuk menyelesaikan penulisan makalah ini penulis menggunakan metode literatur. Metode literatur ini memungkinkan pembahasan permasalahan dilakukan dengan meninjau literatur-literatur yang terkait langsung dan relevan dengan permasalahan yang akan dibahas. Literatur-literatur yang menjadi acuan dalam membahas setiap permasalahan berasal dari paper, artikel, buku, dan jurnal penelitian termasuk literatur-literatur yang ada di jejaring.

\section{BAB II}

\section{ANALISIS (PEMBAHASAN)}

A. Otonomi Daerah dan Good Government.

Harapan baru terbuka kembali setelah kran otonomi daerah dibuka seluas-luasnya yang ditandai dengan terbitnya fajar retormasi tahun 1999 bagi rakyat Indonesia, harapan ini kiranya sangat beralasan karena sistem demokrasi yang sentralistik terpusat orde baru, 
sekarang menjadi desentralisasi dimana daerah diberikan diskresi membangun daerah masingmasing sesuai dengan kemampuan dan kekayaan yang dimiliki. Menurut Departemen Dalam Negeri Republik Indonesia, Good Governance diartikan sebagai pengelolaan pemerintahan yang baik.Kunci utama memahami Good Governance adalah pemahaman atas prinsip-prinsip di dalamnya.Bertolak dari prinsip-prinsip ini akan didapatkan tolak ukur kinerja suatu pemerintahan. Baik buruknya dapat dinilai bila telah bersinggungan dengan unsur prinsipprinsip Good Governance. Menurut Departemen Dalam Negeri dalam Websitenya,Unsur-Unsur Prinsip Good Governance antara lain:

1. Partisipasi masyarakat

Semua masyarakat mempunyai suara dalam pengambilan keputusan, baik secara langsung maupun melalui lembaga-lembaga perwakilan sah yang mewakili kepentingan mereka.Partisipasi menyeluruh tersebut dibangun berdasarkan kebebasan berkumpul dan mengungkapkan pendapat serta kapasitas untuk berpartisipasi.

2. Tegaknya supremasi hukum

Kerangka hukum harus adil dan diberlakukan tanpa pandang bulu, termasuk didalamnyahukum-hukum yang menyangkut hak asasi manusia.

3. Transparansi

Transparansi dibangun atas dasar arus informasi yang bebas. Seluruh proses pemerintahan, lembaga-lembaga dan informasi perlu dapat diakses oleh pihak-pihak yang berkepentingan, dan informasi yang tersedia harus memadai agar dapat dimengerti dan dipantau.

4. Peduli pada stakeholder

Lembaga-lembaga dan seluruh proses pemerintahan harus berusaha melayani semua pihak yang berkentingan.

5. Berorientasi pada konsensus

Tata pemerintahan yang baik menjembatani kepentingan-kepentingan yang berbeda demi terbangunnya sebuah konsensus menyeluruh dalam hal apa yang terbaik bagi kelompokkelompok masyarakat, dan bila mungkin konsensus dalam hal kebijakan-kebijakan dan prosedur-prosedur.

\section{Kesetaraan}

Semua warga masyarakat mempunyai kesempatan memperbaiki atau mempertahankan kesempatan kesejahteraan mereka.

7. Efektifitas dan efisiensi

Proses-proses pemerintahan dan lembagalembaga membuahkan hasil sesuai kebutuhan warga masyarakat dan dengan menggunakan sumber-sumber daya yang ada seoptimal mungkin.

8. Akuntabilitas

Para pengambil keputusan di pemerintah, sektor swasta dan organisasi-organisasi masyarakat bertanggung jawab baik kepada masyarakat maupun kepada lembaga-lembaga yang berkepentingan.Bentuk pertanggung jawaban tersebut berbeda satu dengan lainnya tergantung dari jenis organisasi yang bersangkutan.

9. Visi Strategis

Para pemimpin dan masyarakat memiliki perspektif yang luas dan jauh ke depan atas tata pemerintahan yang baik dan pembangunan manusia, serta kepekaan akan apa saja yang dibutuhkan untuk mewujudkan perkembangan tersebut. Selain itu mereka juga harus memiliki pemahaman atas kompleksitas kesejarahan, budaya dan sosial yang menjadi dasar bagi perspektif tersebut.

\section{B. Reformasi Keuangan Daerah}

Reformasi Pengelolaan Keuangan

NegaraAmanah Undang-Undang Nomor 17 tahun 2003 tentang Keuangan Negara (UU KN). (UU KN) Nomor 17 tahun 2003 antara lain mengharuskan Keuangan Negara (uang rakyat) dikelola oleh pemerintah sebagai "agen" dari rakyat dengan benar dan dapat dipertanggungjawabkan. Oleh karena itu, untuk dapat memastikan bahwa pengelolaan Keuangan Negara telah dilakukan dengan baik oleh pemerintah maka fungsi akuntabilitas dan audit atas pelaporan pengelolaan Keuangan Negara harus berjalan dengan baik. Persoalan akuntabilitas dan audit Keuangan Negara harus dapat dijelaskan agar masyarakat mengetahui bahwa telah ada perubahan paradigmatic dalam pengelolaan keuangan Negara. Persoalan akuntabilitas dalam UU KN No. 17 Tahun 2003, antara lain mengamanatkan 
beberapa asas umum pengelolaan keuangan Negara, yaitu:

1. Akuntabilitas berorientasi pada hasil. Hal ini merupakan landasan penerapan anggaran berbasis kinerja. Artinya, dalam pertanggungjawaban Keuangan Negara, akan dilihat kinerja apa yang telah dicapai oleh Pemerintah dalam menghabiskan dana APBN/APBD. Jika tidak ada kinerja yang dicapai maka tidak boleh se-sen-pun uang Negara dibelanjakan.

2. Profesionalitas. Karena uang Negara merupakan uang rakyat yang harus bernilai maksimal (value for money) bagi kesejahteraan masyarakat, bukan hanya kesejahteraan aparatur Negara. Oleh karena itu, pengelolaan Keuangan Negara harus dikelola secara professional. Penerapan sistem akuntansi keuangan harus benar-benar diterapkan baik untuk APBN maupun APBD.

3. Keterbukaan dalam pengelolaan keuangan Negara. Rakyat berhak tahu kemanadanuntukapaanggaranNegaradibelanjak an.Dalampertanggungjawaban Keuangan Negara, masyarakat perlu diberikan hak untuk mengetahui pertanggungjawaban Keuangan Negara yang dilakukan oleh Negara atau daerah. Minimal, Laporan Pertanggungjawaban Pemerintah perlu dipublikasikan sehingga masyarakat dapat menilai pertanggungjawaban tersebut.

4. Pemeriksaan keuangan oleh badan pemeriksa yang bebas dan mandiri. Ini merupakan amanah baru bagi BPK-RI terutama untuk memeriksa pertanggungjawaban kepala daerah yang sebelumnya tidak ada kewajiban tersebut. Sebelum laporan pertanggungjawaban Pemerintah (Perhitungan Anggaran Negara) dan laporan pertanggungjawaban kepala daerah disampaikan kepada DPR/DPRD, wajib diperiksa terlebih dahulu oleh BPK-RI.

5. Keuangan Negara dikelola secara tertib, taat pada peraturan perundang-undangan, efisien, ekonomis, efektif, transparan, dan bertanggungjawab dengan memperhatikan rasa keadilan dan kepatutan.

6. APBN/APBD mempunyai fungsi otorisasi, perencanaan, pengawasan, alokasi,distribusi,danstabilisasi.Hal berikutnya mengenai audit Keuangan Negara. Audit keuangan Negara dalam peket UU tentang Keuangan Negara ditetapkan dengan UndangUndangNomor 15 Tahun 2004. Dari UU tersebut, secara jelas Badan Pemeriksa Keuangan (BPK) diamanahi suatu tugas berat yaitu melakukan pemeriksaan (audit) atas pengelolaan dan tanggung jawab seluruh unsur keuangan negara.
Beberapa hal yang dirasakan sebagai kemajuan dari penetapan UU Pemeriksaan tersebut antara lain:

1. BPK diberikan kebebasan dan kemandirian dalam menentukan obyek pemeriksaan, perencanaan dan pelaksanaan, penyusunan dan penyajian laporan audit. Meskipun demikian, lembaga perwakilan (DPR, DPD, DPRD Provinsi dan DPRD Kabupaten/Kota) dapat memberikan saran dan mengadakan pertemuan konsultasi dengan BPK dalam perencanaan tugas pemeriksaan. Artinya, apabila lembaga perwakilan merasa memerlukan pelaksanaan audit terhadap entitas yang diawasinya maka dapat meminta bantuan kepada BPK.

2. BPK dapat melakukan audit investigatif (baik berdasarkan temuan awal BPK sendiri maupun pengaduan dari lembaga perwakilan dan masyarakat) guna mengungkapkan adanya indikasi kerugian Negara/dacrah dan/atau unsur pidana.

3. Laporan hasil pemeriksaan BPK (baik hasil audit keuangan maupun audit kinerja) disampaikan kepada lembaga perwakilan dan pemerintah sesuai dengan kewenangannya (LHP Pemerintah Pusat disampaikan kepada DPR, DPD, dan Presiden; LHP Pemerintah Provinsi disampaikan kepada DPRD Provinsi dan Gubernur; dan LHP Pemerintah Kabupaten/Kota disampaikan kepada DPRD Kabupaten/Kota dan Bupati/Walikota). LHP yang telah disampaikan kepada lembaga perwakilan, dinyatakan TERBUKA UNTUK UMUM, kecuali laporan yang memuat rahasia Negara yang diatur dalam peraturan perundangan.

4. Lembaga perwakilan wajib menindaklanjuti hasil pemeriksaan BPK dengan melakukan pembahasan sesuai dengan kewenangannya.

\section{Azas Umum Pengelolaan Keuangan Daerah}

Untuk mencapai suatu anggaran pendapatan dan belanja daerah yang efektif di perlukan azas umum pengelolaan keuangan daerah. Adapun azas umum pengelolaan keuangan daerah berdasarkan Permendagri No. 13 Tahun 2006, antara lain:

1. Keuangan daerah dikelola secara tertib, taat pada peraturan perundangundangan, efektif, efisien, ekonomis, transparan, dan bertanggung jawab dengan memperhatikan azas keadilan, kepatutan, dan manfaat untuk masyarakat.

2. Secara tertib sebagaimana dimaksud pada no.1 adalah bahwa keuangan daerah dikelola secara tepat waktu dan tepat guna yang didukung 
dengan bukti bukti administrasi yang dapat dipertanggungjawabkan.

3. Taat pada peraturan perundang-undangan sebagaimana dimaksud pada no.1 adalah bahwa pengelolaan keuangan daerah harus berpedoman pada peraturan perundangundangan.

4. Efektif sebagaimana dimaksud pada no.1 merupakan pencapaian hasil program dengan target yang telah ditetapkan, yaitu dengan cara membandingkan keluaran dengan hasil.

5. Efisien sebagaimana dimaksud pada no.1 merupakan pencapaian keluaran yang maksimum dengan masukan tertentu atau penggunaan masukan terendah untuk mencapai keluaran tertentu.

6. Ekonomis sebagaimana dimaksud pada no.1 merupakan pemerolehan masukan dengan kualitas dan kuantitas tertentu pada tingkat harga yang terendah.

7. Transparan sebagaimana dimaksud pada no.1
10. Kepatutan sebagaimana dimaksud pada no. adalah tindakan atau suatu sikap yan dilakukan dengan wajar dan proporsional.

11. Manfaat untuk masyarakat sebagaiman dimaksud pada no.1 adalah bahwa keuanga daerah diutamakan untuk pemenuha kebutuhan masyarakat.

\section{Sistem Akuntansi Keuangan Daerah}

Sistem akuntansi keuangan daera memiliki serangkaian prosedur dalam rangk pertanggungjawaban APBD antara lain:

1) Pengumpulan data

2) Pencatatan

3) Penggolongan dan pengikhtisaran

4) Pelaporan keuangan

5) Manual atau aplikasi computer

Karakteristik kebijakan akuntansi dari Sisten Akuntansi Keuangan Daerahmenurut Standa

Prosedur Penyustuan Laporan Keuangau

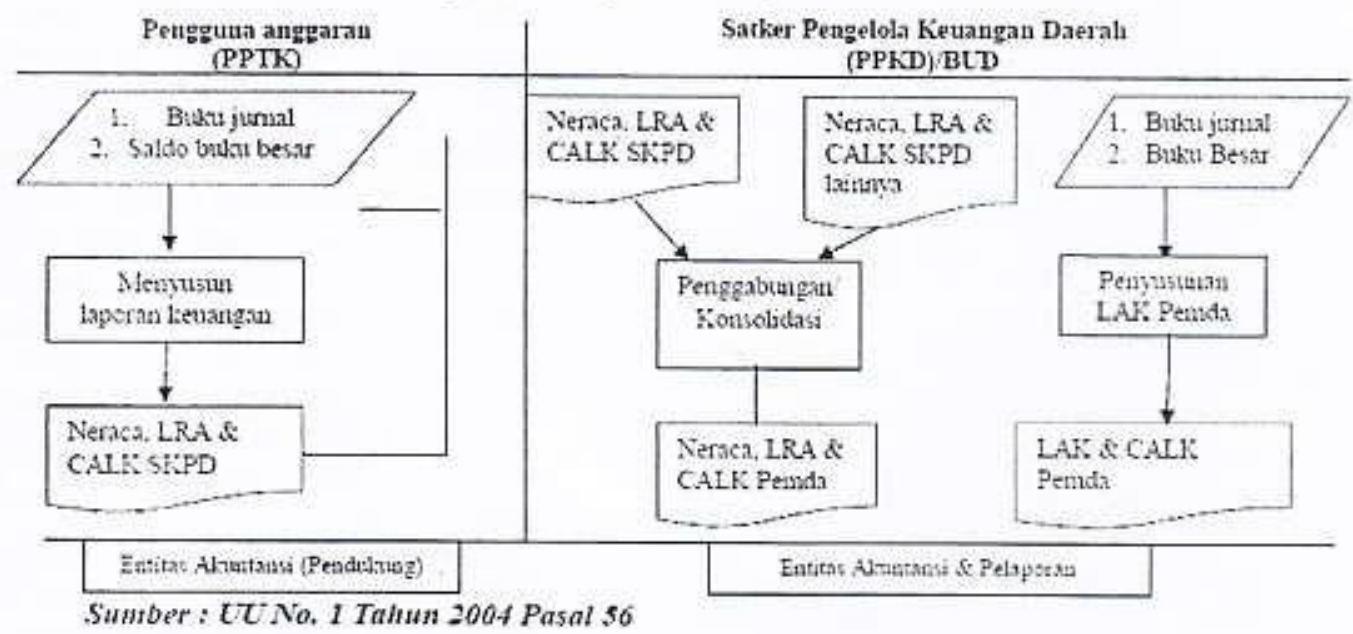

merupakan prinsip keterbukaan yang memungkinkan masyarakat untuk mengetahui dan mendapatkan akses informasi seluasluasnya tentang ketuangan daerah.

8. Bertanggung jawab sebagaimana dimaksud pada no.1 merupakan perwujudan kewajiban seseorang untuk mempertanggungjawabkan pengelolaan dan pengendalian sumber daya dan pelaksanaan kebijakan yang dipercayakan kepadanya dalam rangka pencapaian tujuan yang telah ditetapkan.

9. Keadilan sebagaimana dimaksud pada no.I adalah keseimbangan distribusi kewenangan dan pendanaannya dan atau keseimbangan distribusi hak dan kewajiban berdasarkan pertimbangan yang obyektif.
Akuntansi Pemerintahan No. 24 Tahun 2005 yaitu:

I. Basis akuntansi yang digunakan dalam lapora keuangan pemerintahan basis kas untu pengakuan pendapatan, belanja da pembiayaan dalam Laporan Realisas Anggaran dan basis akrual untuk pengakua aset, kewajiban dan ekuitas dalam neraca.

2. Entitas pelaporan yang menyajikan Lapora Kinerja Keuangan, menyelanggarakat akuntansi dan penyajian laporan keuanga dengan menggunakan sepenuhnya basis akrua baik dalam pengakuan pendapatan, belanja da pembiayaan, maupun dalam pengakuan ase kewajiban dan ekuitas dana. Namun demikian penyajian Laporan realisasi Anggaran teta berdasarkan basis kas. 
Untuk lebih jelasnya, proses penyusunan laporan keuangan di pemerintah derah dapat dilihat pada gambar berikut ;

\section{E. Standar Akuntansi Pemerintahan, Audit Dan Publikasi Atas Laporan Keuangan Pemerintah Daerah Standar Akuntansí Pemerintahan (SAP)} SAP diterbitkan dengan PP No. 24 tahun 2005 tanggal 13 Juni 2005 dan diluncurkan tanggal 6 Juli 2005. Dalam SAP dinyatakan bahwa Pernyataan Standar Akuntansi Pemerintahan (PSAP No. I s.d. PSAP No. 11) berlaku efektif untuk laporan keuangan yang mencakup periode pelaporan yang dimulai pada atau setelah tanggal 1 Januari 2005. Akan tetapi, mengingat kesiapan Pemda yang pada umumnya belum memahami tentang SAP, diberikan kesempatan untuk berbenah sehingga SAP akan diberlakukan mulai tahun anggaran 2007. Pemda yang telah mempunyai sistem akuntansi keuangan daerah (SAKD) berbasis Kepmendagri No. 29 tahun 2002 yang mungkin belum sesuai dengan SAP perlu segera menyiapkan diri untuk melakukan penyesuaian agar dalam tahun anggaran 2007, SAP dapat diterapkan secara benar.

Komite SAP perlu memaksimalkan kegiatan sosialisasi, minimal ke "kantong-kantong" akuntan yang selanjutnya akan mensosialisasikan diwilayah masing-masing, seperti IAI Wilayah dan Perwakilan BPK-RI. Selanjutnya, Pemerintah Provinsi/Kabupaten/Kota tersebut meminta pelatihan lebih lanjut sehubungan dengan penerapan SAP. Pemda telah sedikit banyak menyesuaikan sistem akuntansinya dengan SAP dalam penyusunan laporan keuangat tahun anggaran 2005 dan 2006, maka diharapkan tidak akan banyak mengalami kesulitan dalam penerapan SAP mulai tahun anggaran 2007. Apabila ternyata masih ada beberapa hal yang dirasa sulit penerapannya. maka dapat dikonsultasikan dengan IAI, BPKRI, dalam pelaksanaan audit atas laporan keuangan tahun anggaran 2007 juga dapat melakukan penyesuaian seperlunya sehingga laporan keuangan pemerintah daerah tahun anggaran 2007 dan seterusnya dapat tetap menyajikan laporan keuangan secara Wajar dan mendapatkan opini Wajar Taupa Pengecualian.

Hal tersebut tentunya akan memudahkan bagi Penda yang saat ini telah menerapkan SAKD berdasarkan Kepmendagri 29 tahun 2002 (dengan atau tampa mengacu pada SAP) karena hanya perlu melakukan penyesuaianpenyesuaian saja. Sedangkan bagi Pemda yang sama sekali belum menerapkan SAKD, masih harus menyusun SAKD sesuai SAP. Padahal kita pahami bersama bahwa melakukan penyesuaian akan lebih mudah dibandingkan dengan melakukan penyusunan. Laporan keuangan akan tetap tanpa SAP (ada jika telah diterapkan sistem akuntansi) dan sebaliknya, laporan keuangan hanya menjadi "mimpi" tanpa sistem akuntansi, walaupun tersedia SAP.

Audit atas laporan keuangan Pemerintah Daerah

Dalam audit, Tim Auditor BPK terlebih dahulu melakukan evaluasi atas struktur pengendalian intern.Berkaitan dengan pemeriksaan substansif atas angka-angka yang disajikan dalam laporan keuangan untuk menilai kewajaran laporan keuangan terutama asersi manajemen berupa penilaian, kelengkapan, keberadaan/keterjadian, kecukupan pengungkapan, dan klasifikași. Apabila ada asersi manajemen yang berdasarkan pemeriksaan kurang memadai atau tidak disajikan secara wajar, maka akan dilakukan usulan koreksi kepada manajemen Pemda. Beberapa usulan koreksi didiskusikan secara cermat untuk menghindari ketidakjelasan dalam laporan keuangan auditan. Dengan demikian, laporan keuangan auditan telah disusun sesuai prinsip akuntansi yang ditetapkan dalam berbagai peraturan perundangan dan selanjutnya dipublikasikan melalui surat kabar.

Opini yang disajikan BPK-R1 tidak sesuai dengan Standar Audit Pemerintahan (SAP) yang diterbitkan BPK-RI dan Standar Profesional Akuntan Publik (SPAP) khususnya Pernyataan Standar Audit (PSA) Nomor 62 tentang Audit atas Entitas Pemerintah yang diterbitkan IAI. Menurut PSA No. 2 tentang audit Kepatuhan yang diterapkan atas Entitas Pemerintahan dan Penerima Lain Bantuan Keuangan Pemerintah, auditor wajib :

a. Menerapkan aturan Pertimbangan atas Kecurangan dalam Audit Laporan Keuangan, dan Unsur Tindakan Melanggar Hukum oleh Klien, yang berkaitan dengan pendeteksian salah saji sebagai akibat dari unsur pelanggaran peraturan perundang-undangan.

b. Melaporkan kepatuhan entitas yang diaudit terhadap peraturan perundang-undangan dan terhadap pengendalian intern dalam audit yang dilaksanakan berdasarkan Standar Audit Pemerintahan,

Audit Laporan Keuangan Pemda harus didasarkan pada Standar Akuntansi Pemerintahan karena Pemda merupakan entitas pemerintah. Diperlukannya audit kepatuhan 
karena entitas pemerintah dibatasi oleh banyak peraturan perundangan.

\section{Penyajian dan publikasi atas laporan} keuangan Pemerintah Daerah

Untuk menghasilkan laporan keuangan yang relevan, handal, dan dapat dipercaya, Pemerintah Daerah harus memiliki sistem akuntansi yang handal.. Laporan Keuangan Pemerintah Daerah merupakan komponen penting untuk menciptakan akuntabilitas sector publik dan merupakan salah satu alat untuk mengukur kinerja finansial Pemerintah Daerah. Bagi pihak eksternal, Laporan Keuangan Pemerintah Daerah yang berisi informasi keuangan daerah akan digunakan sebagai dasar pertimbangan untuk pengambilan keputusan ekonomi, social, dan politik. Sedangkan bagi pihak intern Pemerintah Daerah, laporan keuangan tersebut dapat digunakan sebagai alat penilaian kinerja.

Laporan Keuangan Pemerintah Daerah yang disajikan pada media masa terutama dimaksudkan agar masyarakat dapat mengetahui beberapa pendapat dan untuk apa saja keuangan daerah. Hal tersebut sesuai dengan azas transparansi dan akuntabilitas pengelolaan keuangan daerah sebagaimana Pasal 4 PP 105 tahun 2000 tentang Pengelolaan dan Pertanggungiawaban Keuangan Daerah yang menyetakan bahwa Pengelolaan Keuangan Daerah dilakukan secara tertib, taat pada peraturan perundang-undangan yang berlaku, efisien, efektif, transparan dan bertanggungjawab dengan memperhatikan asas keadilan dan kepatuhan.

Penyajian laporan keuangan pada surat kabar akan menunjukkan kesiapan Pemda akan akuntabilitas dan transparansi pengelolaan dan pertanggungjawaban keuangan daerah. Karena diyakini bahwa setelah penyajian tersebut, akan banyak mendapat komentar atau penilaian dan evaluasi dari berbagai pihak. Pemeriksaan Pengelolaan dan Pertanggungiawaban Keuangan Negara yang menyatakan bahwa laporan hasil audit BPK yang telah disampaikan kepada lembaga perwakilan (DPR/DPD/DPRD) dan terbuka untuk umum.

\section{F. Entitas Pelaporan dan Entitas Akuntansi Berdasarkan Peraturan Pemerintah}

No.24 Tahun 2005, suatu entitas pelaporan ditetapkan didalam peraturan perundangundangan, yang umumnya bercirikan:

I. Entitas tersebut dibiayai oleh APBN atau dibiayai oleh $A P B D$ atau mendapat pemisahan kekayaan dari anggaran
2. Entitas tersebut dibentuk dengan peraturan perundang-undangan.

3. Pimpinan entitas tersebut adalah pejabat pemerintah yang diangkat atau pejabat negara yang ditunjuk atau yang dipilih oleh rakyat, dan

4. Entitas tersebut membuat pertanggungjawaban baik langsung maupun tidak langsung kepada wakil rakyat sebagai pihak yang menyetujui anggaran.

Entitas pelaporan adalah unit pemerintahan yang terdiri dari satu atau lebihentitas akuntansi yang menurut ketentuan peraturan perundang-undangan wajib menyampaikan laporan pertanggungjawaban berupa laporan keuangan, yang terdiri dari:

a) Pemerintah Pusat

b) Pemerintah Daerah

c) Satuan organisasi di lingkungan pemerintah pusat/daerah atau organisasi lainnya, jika menurut peraturan paerundang-undangan satuan organisasi dimaksud wajib menyajikan laporan keuangan.

Entitas Akuntansi menurut Peraturan Pemerintah No.24 Tahun 2005, merupakan penggunan anggaran/pengguna barang sebagai entitas akuntansi menyelenggarakan akuntansi dan menyampaikan laporan keuangan sehubungan dengan anggaran/barang yang dikelolanya yang ditujukan kepada entitas pelaporan.

\section{G. Peran Akuntan Dalam Pemerintah Daerah}

Menurut Basri, Edwar Endarto, (2009) peran dan peluang akuntan masih terbuka lebar seiring dengan pertumbuhan perusahaan baik yang listing di bursa efek Indonesia maunpun perusahaan privat alias sebelum go publik, dimana jumlah akuntan di indonesia tergolong masih sedikit dibandingkan dengan negara ASEAN lainnya, struktur usia akuntan publik di Indonesia 39\% diantaranya telah berusia diatas 60 tahun atau $67 \%$ di atas 50 tahun, tidak semua lulusan Ujian Sertifikasi Akuntan Publik (USAP) (Indonesia CPA) menjadi Akuntan Publik (hanya 26\% yang menjadi Akuntan Publik (pertumbuhan akuntan publik di Indonesia sangat lambat, akibatnya kira-kira 10 tahun kedepan ketika akuntan publik yang berusia 60tahun mundur atau sudah tidak praktek, akan terjadi penuruman iumlah 
akuntan publik yang signifikan di Indonesia, karena itu Program Profesi Akuntansi (PPAk) harus segera digalakkan di seluruh Indonesia untuk menjawab peluang tersebut, hal ini penting supaya perusahaan dapat mematuhi IFRS dalam menyusun laporan keuangan yang akan dimulai tahun 2012 nanti artinya semakin besar peluang dan peran akuntan di Indonesia.

Menurut Menteri Keuangan Sri Mulyani,Kompas 16 Juli 2008, Susah Cari Akuntan Berkualitas, Hasil Audit BPK terhadap kualitas laporan keuangan pemerintah pusat, kementerian/lembaga serta pemerintah daerah sebagian besar belum memuaskan. rendahnya kualitas ini salah satunya disebabkan oleh ketersediaan SDM akuntansi dan keuangan yang sangat langka di lingkungan pemerintahan."Terutama di lingkungan biro-biro keuangan, perencanaan dan perlengkapan dan Pemda, sebenarnya mudah menemukan sekolah akuntansi namun sulit menemukan akuntan dengan kualitas yang brilian. "Jadi bukan susah cari supply kuantitas tapi kualitas.

Pokok-Pokok Regulasi Akuntan Publik Peraturan Menteri Keuangan (PMK) No. PMK 17/PMK.01/2008 mengatur tentang hak kewajiban Akuntan Publik dan Kantor Akuntan Publik

Hak Ekslusif Akuntan Publik yaitu ;

a. Jasa audit atas laporan keuangan

b. Jasa pemeriksaan atas laporan keuangan prospektif

c. Jasa pemeriksaan atas laporan informasi keungan proforma

d. Jasa review atas laporan keuangan

e. Jasa atestasi lainnya sebagaimana tercantum dalam di Standar Profesional Akuntan Publik (SPAP)

Jasa selain assurance kepada klien audit laporan keuangan yaitu ;

a. Jasa penyiapan catatan akuntansi dan laporan keuangan

b. Jasa penilaian

c. Jasa perpajakan

d. Jasa audit internal

e. Jasa system teknologi informasi

f. Jasa penugasan sementara

g. Jasa penunjang litigasi

h. Jasa hukum

i. Jasa rekrutmen manajemen senior

j. Jasa keuangan korporat

\section{Peningkatan Kebutuhan Jasa Akuntan}

Menurut PPAJP Departemen Keuangan semakin banyak dibutuhkan jasa akuntan untuk mengaudit atau memberikan jasanya kepada entitas antara lain ;

a. Perusahaan Terbuka

b. Perusahaan pengerah dana masyarakat seperti asuransi, dana pension, perbankan, reksa dana.

c. Perusahaan dengan asset atau omset 50 miliar atau lebih.

d. BUMN, BUMD, Perusahaan daerah lainnya,

e. Entitas penerima kredit bank.

f. Dana kampanye, hibah dan lain-lain.

g. Rencanan BPK untuk memberikan kewenangan audit terhadap Pemerintah Daerah.

Melihat peran dan kebutuhan terhadap akuntan yang telah digariskan oleh Departemen Keuangan maka semakin menambah parjang deretan bahwa peran akuntan sangatlah strategis dan memainkan peranan penting karena itu scbagai akuntan harus mampu menjemput bola meningkatkan kemampuan professional supaya dalam melakukan dan memberikan jasa atestasi dan non atestasi kepada klien sesuai dengan kode etik dan harapan masyarakat yaitu dapat menemukan kemungkinan-kemungkinan terjadinya penyimpangan (fraud) terhadap laporan keungan pemerintah daerah, apalagi organisasi sektor public (pemda) sangatlah unik dan punya karakteristik sendiri tidak seperti laporan keuangan sektor privat yang sudah umum dan biasa serta tersebar dimana-mana, lain halnya dengan laporan keungan pemerintah daerah masih sangat baru dan perlu kajian mendalam untuk memahaminya, karena itu akuntan harus selalu meng-update pengetahuannya supaya ekspektasi besar masyarakat dapat dipenuhi. Disamping itu di era sekarang, ekspektasi masyarakat dan pemerintah dalam hal ini Menteri Keuangan menaruh harapan besar bahwa keuangan daerah harus dikelola dengan baik berbagai regulasi telah dikeluarkan supaya akuntabilitas laporan keungan pemerintah daerah dapat diwujudkan apa lagi saat ini opini sudah diberikan kepada laporan keungan pemerintah daerah, berbeda di era orde baru belum ada opini atas laporan ketangan, sudah barang tentu semua pemerintah daerah ingin meraih opini yang terbaik yaitu wajar tanpa 
pengecualian (WTP) mengapa, karena dengan WTP secara otomatis sudah mencerminkan pengelolaan dan akuntabilitas keuangan yang baik yang pada akhirnya ada ekspektasi baru dimana apabila pemerintah daerah, berhasil meraih opini WTP maka akan diberikan hadiah atau bonus begitu pula bagi yang disclaimer juga diberikan sanksi atau denda adilkan?.

Maka dari itu peran akuntan ditunggu-tunggu oleh public supaya pengelolaan keuangan daerah semakin hari semakin baik yang pada akhirnya mampu mensejahterakan hidup rakyat didaerah, saat ini tercatat ada 508 pemerintah daerah yang lahir dari 33 propinsi, jika dikalkulasi dengan asumsi 1 Pemda rata-rata memiliki 25 SKPD dan 1 SKPD memerlukan I Akuntan, maka kebutuhan akuntan yang bekerja di Pemerintah Daerah adalah 508 Pemda $\times 25$ SKPD $=12.700$, maka diperlukan 12.700 Akuntan untuk mengisi disetiap SKPD Pemerintah Daerah di Indonesia.

\section{H. Opini Auditor}

\section{KonvergensiWajar Tanpa Pengecualian (WTP) Unqualified Opinion}

Bangsa Indonesia memasuki era bart pengelolaan keuangan negara baru sekitar 6 tahun lalu dengan disahkannya paket Undang. Undang Pengelolaan Keuangan Negara yang meliputi UU Nomor 17 tahun 2003 tentang Keuangan Negara, Undang-Undang Nomor 1 tahun 2004 tentang Perbendaharaan Negara dan Undang-Undang Nomor 15 tahun 2004 tentang Pemeriksaan Pengelolaan dan Tanggung Jawab Keuangan Negara. Paket Undang-Undang ini sekaligus menggantikan peraturan perundang-undangan yang sudah berlaku semenjak jaman penjajahan dan sekaligus juga menandai dimulainya reformasi keuangan negara menuju transparansi dan akuntabilitas pengelolaan keuangan.

Dalam rangka pertanggungjawaban pelaksanaan Anggaran Pendapatan Belanja Daerah (APBD), sebagai bagian dari siklus penganggaran, maka Pemerintah Daerah menyusun Laporan Keuangan Pemerintah Daerah (LKPD) sebagaimana diamanatkan pasal 31 UU No 17/2003. LKPD terdiri dari ;

1. Laporan realisasi APBD,

2. Neraca,

3. Laporan Arus Kas

4. Serta Catatan atas Laporan Keuangan yangmana disusun dan disajikan sesuai dengan standar akuntansi pemerintahan yang telah ditetapkan melalui PP Nomor 24 tahun 2005.
LKPD inilah yang menjadi objek pemeriksaan BPK sebelum Gubernur/Walikota/Bupati mengajukan rancangan peraturan daerah kepada DPRD.

MenurutI Wayan Agus Eka, Bali Post, tanggal 18 Juli 2009, kelemahan-kelemahan dalam LKPD di Indonesia sebenarnya dapat disarikan menjadi beberapa bagian besar adalah :

1. Kelemahan dalam pengelolaan pendapatan daerah. Kelemahan ini terindikasi dari temuan BPK berupa dugaan penggelapan pajak, kekurangan perhitungan atas pendapatan jasa giro dan keterlambatan pengenaan denda.

2. Kelemahan pengelolaan aset daerah yang tergambarkan dari temuan BPK berupa kelemahan sistem pengelolaan aset tetap berupa tidak tertibnya penatausahaan.

3. Kelemahan pengelolaan investasi daerah yang dapat dilihat dari temuan BPK pada investasi.

4. Kelemahan terakhir adalah kelemahan dalam sistem pengendalian internal yang tidak menggunakan mekanisme anggaran sehingga melanggar ketentuan dalam pasal 3 ayat (6) Undang-Undang No 1 Tahun 2004 yang menyebutkan bahwa semua penerimaan yang menjadi hak dan pengeluaran yang menjadi kewajiban daerah dalam tahun anggaran yang bersangkutan harus dimasukkan dalam APBD. Untuk mengatasi kelemahan-kelemahan tersebut perlu dilakukan yaitu ;

1. Penyusunan Peraturan Kepala Dacrah harus sesuai Standar Akuntansi Pemerintahan (SAP), sebagaimana diamanatkan oleh Pasal $97 \mathrm{PP}$ Nomor 58 Tahun 2005 tentang Pengelolaan Keuangan Daerah. SAP pada hakikatnya hanya memberikan gambaran secara umum prinsipprinsip akuntansi sektor publik (pemerintahan) yang berlaku baik untuk pemerintah pusat maupun pemerintah daerah. Prinsip-prinsip ini harus dijabarkan dalam bahasa yang lebih teknis oleh masing-masing entitas untuk menjadi pedoman dalam penyusunan laporan keuangan. Kebijakan akuntansi ini menjadi penting karena menjadi dasar bagi pengelola keuangan daerah untuk menyusun LKPD sehingga harus bersifat komprehensif yang meliputi kebijakan untuk pengeluaran/ penerimaan kas, akuntansi aset tetap, investasi, hutang, persediaan,dan piutang.

2. Kebijakan akuntansi. Akuntan BPK juga memiliki kepentingan untuk menentukan kesesuaian penyajian laporan keuangan dengan standar yang telah ditetapkan. BPK juga akan melakukan penilaian apakah kebijakan akuntansi pemerintah sudah sejalan dengan SAP. Mengingat penetapan kebijakan ini berhubungan erat dengan berbagai stakeholder maka political will dari cksekutif daerah sangat 
diperlukan untuk pengelolaan keuangan daerah yang lebih baik.

3. Pembenahan sistem pengelolaan aset Pemerintah Daerah. Sistem pengelolaan aset tetap yang baik dimulai dari penyusunan seperangkat peraturan yang berisi prosedurprosedur pengelolaan aset tetap yang meliputi prosedur bagaimana aset tersebut diakui oleh pemda dalam sistem akuntansinya, siapakah yang bertanggung jawab atas penggunaan, pengelolaan dan pemeliharaannya. Karena kedepan akan menggunakan fair value jadi jika asset sudah tertata dengan baik maka untuk diadakan appraisal lebih mudah.

4. Perbaikan sistem pengendalian internal. Sistem pengendalian internal merupakan komponen penting dalam pengelolaan dan pengawasan keuangan daerah dengan SPI yang baik maka akan lahir pengawasan dan evaluasi secara sistemik yang lebih efektif dan efisien. Bawasda harus mampu mengidentifikasi sistem pengendalian yang tidak berjalan, untuk kemudian mengusulkan perbaikan atau penggantian. Dengan kata lain Bawasda harus melakukan pengujian ini secara berkelanjutan untuk menentukan apakah masih berjalan dengan efektif atau relevan.

5. Pemanfaatan teknologi informasi dalam pengelolaan keuangan daerah. Pengelolaan keuangan daerah membutuhkan terintegrasinya berbagai sistem pendukungnya antara lain sistem akuntansi, sistem pengelolaan aset, sistem penganggaran, sistem procurement dan lain sebagainya. Dengan kemajuan teknologi maka sistem-sistem ini dapat dibuat dengan berbasis komputer dan saling terhubung satu sama lainnya dengan basis jaringan, penyederhanaan proses, minimalisasi kemungkinan kecurangan, penghematan biaya dalam jangka panjang serta ketepatan informasi yang dihasilkan.

6. Perbaikan kualitas sumber daya manusia dan Akuntan di setiap LKPD.Terwujudnya tata kelola keuangan daerah yang baik sangat ditentukan oleh kualitas akuntan yang menyusun dan melaksanakan pengelolaan keuangan negara. Ketua BPK sendiri pernah menyatakan bahwa salah satu penyebab opini disclaimer adalah kualitas SDM dan akuntan yang tidak mendukung. Diperlukan perbaikan penanganan SDM khususnya di bidang keuangan/akuntansi (akuntan) yang antara lain berupa penyusunan standar kompetensi minimal yang harus dipenuhi serta pelaksanaan program pendidikan/pelatihan keuangan yang berkelanjutan.

Profil Opini atas Laporan Keuangan Pemerintah Daerah (LKPD) di Indonesia Tahun 2005-2008

Pemeriksaan keuangan adalah pemeriksaan atas laporan keuangan yang bertujuan untuk memberikan keyakinan yang memadai (reasonable assurance) bahwa laporan keuangan telah disajikan secara wajar dalam semua hal yang material, sesuai dengan prinsip akuntansi yang berlaku umum di Indonesia atau basis akuntansi komprehensif lainnya.

Pemeriksaan atas laporan keuangan dilakukan dalam rangka memberikan pendapat/opini atas kewajaran informasi keuangan yang disajikan dalam laporan keuangan dengan mendasarkan pada

1. Kesesuaian dengan standar akuntansi pemerintahan dan atau prinsip-prinsip akuntansi yang ditetapkan dalam berbagai peraturan perundang-undangan;

2. Kecukupan pengungkapan (adequate disclosure);

3. Kepatuhan terhadap peraturan perundangundangan; dan

4. Efektivitas system pengendalian intern.

Opini merupakan pernyataan profesional pemeriksa mengenai kewajaran informasi keuangan yang disajikan dalam laporan keuangan. Terdapat 4 (empat) jenis opini yang dapat diberikan oleh pemeriksa.

- Opini Wajar Tanpa Pengecualian - WTP (unqualified opinion); menyatakan bahwa laporan keuangan telah disajikan dan diungkapkan secara wajar dalam semua hal yang material dan informasi keuangan dalam laporan keuangan dapat diandalkan.

- Opini Wajar Dengan Pengecualian - WDP (qualified opinion); menyatakan bahwa laporan keuangan telah disajikan dan diungkapkan secara wajar dalam semua hal yang material, kecuali untuk dampak hal-hal yang berhubungan dengan yang dikecualikan, sehingga informasi keuangan dalam laporan keuangan yang tidak dikecualikan dalam laporan keuangan dapat diandalkan.

- Opini Tidak Wajar - TW (adverse opinion); meyatakan bahwa laporan keuangan tidak disajikan dan diungkapkan secara wajar dalam semua hal yang material, sehingga informasi keuangan dalam laporan keuangan tidak dapat diandalkan.

- Peryataan Menolak Memberikan Opini atau Tidak Memberikan Pendapat - TMP (disclaimer of opinion); menyatakan bahwa laporan keuangan tidak dapat diperiksa sesuai dengan standar pemeriksaan. Dengan kata lain, pemeriksa tidak dapat memberikan keyakinan 
bahwa laporan keuangan bebas dari salah saji material, sehingga informasi keuangan dalam laporan keuangan tidak dapat diandalkan.

- Rekapitulasi Opini LKPD TA 2005-2008

\begin{tabular}{|c|c|c|c|c|}
\hline Jenis Opini & 2005 & 2006 & 2007 & 2008 \\
\hline Wajar Tanpa Pengecualian (WTP) & $21(6 \%)$ & $4(1 \%)$ & $4(1 \%)$ & $12(3 \%)$ \\
\hline $\begin{array}{l}\begin{array}{l}\text { Wajar } \\
\text { (WDP) }\end{array} \\
\end{array}$ & $289(83 \%)$ & $326(71 \%)$ & $273(59 \%)$ & $307(71 \%)$ \\
\hline Tidak Wajar (TW) & $14(4 \%)$ & $26(6 \%)$ & $59(13 \%)$ & $28(6 \%)$ \\
\hline $\begin{array}{l}\text { Tidak Mermberikan Pendapat } \\
\text { (IMP) }\end{array}$ & $26(7 \%)$ & $105(22 \%)$ & $124(27 \%)$ & $87(20 \%)$ \\
\hline Jumlah Entitas LKPD & 350 & 461 & 460 & 434 \\
\hline
\end{tabular}

Sumber : BPK RI \& diolah

Dari rekapitulasi diatas dapat dianalisa bahwa pada 4 tahun terakhir periode 2005-2008, ternyata opini wajar tanpa pengecualian semakin tahun cenderung semakin menurun jika dilihat dari persentase jumlah entitas LKPD yang mendapat opini wajar tanpa pengecualian tahun 2005 dimana 21 atau $6 \%$ LKPD dengan jumlah entitas LKPD 350, tahun 2006 dimana 4 atau 1\% LKPD dengan jumlah entitas LKPD 461, tahun 2007 dimana 4 atau $1 \%$ LKPD dengan jumlah entitas LKPD 460 , dan tahun 2008 dimana 12 atau $3 \%$ LKPDdengan jumlah entitas LKPD 434.

- Grafik Perkembangan Opini LKPD TA 2005-2008

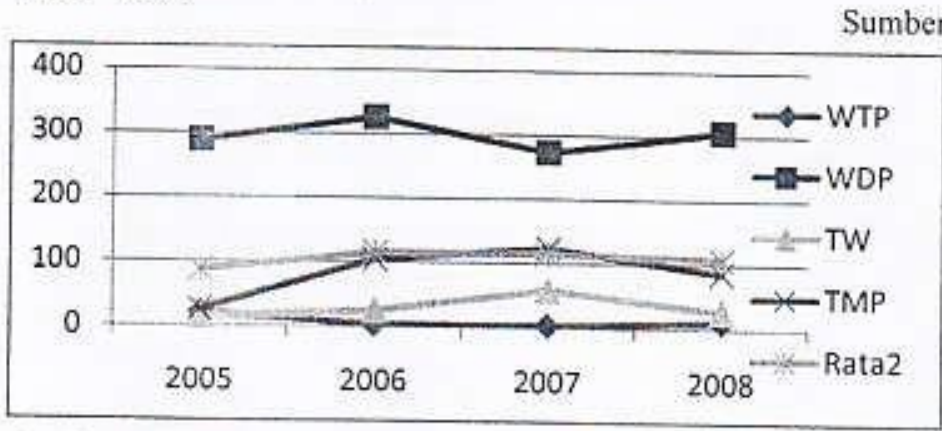

Sumber : BPK RI \& diolah

Dari grafik diatas bahwa perkembangan opini audit LKPD masih didominasi oleh wajar dengan pengecualian (WDP) baik di kabupaten, kota maupun propinsi disusul oleh opini tidak memberikan pendapat (TMP), kemudian tidak wajar (TW) dan terakhir adalah wajar tanpa pengecualian (WTP) jika disimpulkan tata urutan opini LKPD baik kabupaten, kota dan propinsi sebagai berikut :
1. Opini LKPD wajar dengan pengecualian (WDP)

2. Opini LKPD tidak memberikan pendapat TMP)

3. Opini LKPD tidak wajar (TW)

4. Opini LKPD wajar tanpa pengecualian (WTP)

- Grafik Opini LKPD TA 2008 berdasarkan tingkat Pemerintahan

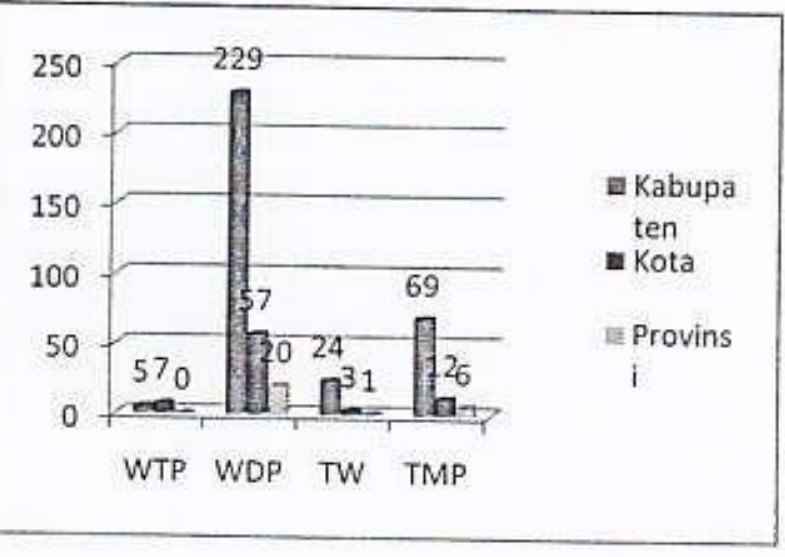

Sumber : BPK RI\& diolah

Dari grafik diatas dapat dianalisis bahwa opini laporan keuangan

I. Wajar tanpa pengecualian (unqualified oipinion) adalah 5 LKPD kabupaten, 7 LKPD kota, sementara LKPD rovinsi tidak ada yang memperoleh opini wajar tanpa pengecualian (unqualified opinion)

2. Wajar dengan pengecualian (qualified opinion) adalah 229 LKPD kabupaten, 57 LKPD kota, sementara 20 LKPD diraih provinsi.

3. Tidak wajar (adverse opinion) adalah 24 LKPD kabupaten, 3 LKPD kota, sisanya 1 diaraih LKPD propinsi.

4. Menolak Memberikan Opini atau Tidak Memberikan Pendapat (disclaimer of opinion) adalah 69 LKPD kabupaten, 12 LKPD kota, dan sebanyak 6 LKPD propinsi. pemerintah daerah (LKPD) adalah; 
Wajar Tanpa Pengecualian (Unqualified opinion)saat ini bukanlah suatu angan-angan belaka, karena beberapa Pemerintah Daerah sudah berhasil mencapainya.Terpenting adalah komitmen dan konsistensi adalah langkah selanjutnya karena dengan komitmen dan konsistensi itulah LKPD tidak hanya sekadar menjadi alat pertanggungjawaban namun lebih dari itu mampu memberikan manfaat berupa informasi dalam proses pengambilan keputusan dalam rangka mensejahterakan Rakyat Republik Indonesia tercinta ini.

\section{BAB III KESIMPULAN DAN SARAN}

A. Kesimpulan.

1. Pemerintah Daerah(PEMDA) harus mampu memanfaat momentum otonomi daerah dengan menerapkan prinsip-prinsip good governance untuk mewujudkan perbaikan pelayanan kepada public.

2. Dengan transparansinya dan publikasi laporan keuangan maka pemerintah sebagai agen dapat mempertanggungjawabkannya kepada prinsipalnya yaitu rakyat. Maka pemerintah daerah dapat menjalankan fungsi utamanya sebagai pelayan masyarakat (public service) karena rakyat menuntut daya guna dan hasil guna dari keuangan yang dikelola oleh pemerintah daerah (Mardiasmo, 2002, Bastian,2001, Halim,2002) dalam Muhsin (2004).

3. Laporan Keuangan Pemerintah Daerah komponen penting untuk menciptakan akuntabilitas sector publik dan alat untuk mengukur kinerja finansial Pemerintah Dacrah. Bagi pihak eksternal, Laporan Keuangan Pemerintah Daerah yang berisi informasi keuangan daerah akan digunakan sebagai dasar pertimbangan untuk pengambilan keputusan ekonomi, social, dan politik. Sedangkan bagi Pemerintah Daerah, laporan keuangan digunakan sebagai alat penilaian kinerja.

4. Akuntan, baik sebagai akuntan pemerintah (BPK) maupun akuntan yang inheren dengan pemerintah daerah masih sangat diperlukan perannya untuk mampu menciptakan perbaikan tata kelola keuangan daerah menuju opini wajar tanpa pengecualian LPKD.

5. Perolehan opini wajar tanpa pengecualian (WTP) bagi laporan keuangan pemerintah daerah (LKPD) cenderung mengalami penurunan dari tahun ke tahun bila dilihat dari persentase jumlah entitas LKPD dimana tahum 2005 adalah $4 \%$, tahun $20061 \%$, tahun 20071 $\%$, dan tahun 2008 adalah $3 \%$.

6. Luas dan banyaknya jumlah pemerintah daerah data terakhir dari BPK menyebutkan 508
Pemerintah Daerah yang ada di Indonesia, yang lahir dari 33 Propinsi. Dengan asumsi 1 Pemda rata-rata memiliki 25 SKPD, dan 1 SKPD memerlukan 1 Akuntan berarti, 508 Pemda $\times 25$ SKPD $=12.700$ SKPD, maka diperlukan 12.700 Akuntan untuk bekerja di setiap SKPD yang ada di 508 Pemerintah Daerah di Indonesia.

7. Menteri keuangan telah mengumumkan bahwa bagi pemerintah daerah dimana laporan keuangannya mendapat opini wajar tanpa pengecualian maka akan diberikan reward dan yang belum memenuhi opini tersebut juga akan diberikan punishment.

B. Saran

1. Kepala Daerah harus memiliki komitmen yang tinggi untuk melakukan perubahan sehingga dapat menerapkan best practice dan akuntabel dalam mengelola uang rakyat untuk kesejahteraan rakyat.

2. Penetapan Peraturan Kepala Daerah tentang keuangan harus sesuai dengan Standar Akuntansi Pemerintahan (SAP) No 24 Tahun 2005

3. Pemerintah Daerah perlu memperbaiki sistem pengendalian internal yang ada disetiap Satuan Kerja Perangkat Daerah (SKPD)

4. Pemerintah Daerah harus mampu memanfaatan teknologi informasi dalam pengelolaan keuangan daerah. Pengelolaan keuangan daerah membutuhkan terintegrasinya berbagai sistem pendukungnya antara lain sistem akuntansi, sistem pengelolaan aset, sistem penganggaran, sistem procurement dan lain sebagainya

5. Perlu penambahan dan perbaikan kualitas sumber daya manusia dan Akuntan di setiap SKPD untuk menghasilkan LKPDunqualified opinion.

\section{REFERENSI}

Badan Pemeriksa Keuangan Republik Indonesia, www.bpk.go.id

Bastian, Indra, (2001),Akuntansi Sektor Publik di Indonesia, BPFE UGM, Jogjakarta

Departemen Dalam Negeri, www.depdagri.go.id Edward, Basri Indarto, Profesi Akuntan Publik di Indonesia: Peluang Tantangan dan Regulasi, Paper, (Sosialisasi Regulasi \& Kode Etik Akuntan Tahun 2010), 2009.

1 Wayan Agus Eka, Bali Post, tanggal 18 Juli 2009

Keputusan Menteri Dalam Negeri No. 29 tahun 2002 Kompas, 16 Juli 2008.

Muhsin, Pengarwh Desentralisasi, Sistem Pengendalian Akuntansi, dan Komitmen Organisasi Terhadap Kinerja Pemerintah 
Daerah (PEMDA) Pada Provinsi DIY (Kota Jogjakarta, Kabupaten Sleman, Kabupaten Bantul, dan Kabupaten Kulon Progo), 2004, Tesis, Magister Akuntansi FE UGM.

Peraturan Menteri Dalam Negeri No. 13 Tahun 2006.

Peraturan Menteri Keuangan (PMK) No. PMK 17/PMK.01/2008 Peraturan Menteri Keuangan mengatur tentang hak kewajiban Akuntan Publik dan Kantor Akuntan Publik

Peraturan Pemerintah 105 tahun 2000 tentang

Pengelolaan dan Pertanggungjawaban

Keuangan Daerah

Peraturan Pemerintah No. 24 Tahun 2005, Tentang Standar Akuntansi Pemerintah.

Peraturan Pemerintah Nomor 58 Tahun 2005 tentang Pengelolaan Keuangan Daerah
Undang-Undang Nomor 1 tahun 2004 tentang Perbendaharaan Negara

Undang-Undang 15 Tahun 2004 tentang Pemeriksaan Pengelolaan dan Pertanggungjawaban Keuangan Negara

Undang-Undang Nomor 17 tahun 2003 tentang Keuangan Negara.

www.ppajp.depkeu.go.id. 